\title{
Bacteriuria in patients undergoing prostatectomy
}

\author{
MELANIE WILLIAMS, ${ }^{*}$ DJ HOLE $\dagger$
}

\begin{abstract}
From the * Department of Bacteriology and Immunology, Western Infirmary, Glasgow, and the †West of Scotland Cancer Surveillance Unit, Ruchill Hospital, Glasgow.
\end{abstract}

SUMMARY A review of the literature revealed that the reported incidence of bacteriuria arising before and after prostatectomy varied considerably, that there had been little investigation of the organisms isolated, and that the value of chemoprophylaxis at the time of prostatectomy was unproven.

Using standard criteria and technical procedures, 248 patients undergoing prostatectomy were studied over a two-and-a-half-year period. Preoperative bacteriuria occurred in $28 \%$ of patients. The incidence was significantly increased in patients catheterised before operation (44\%) compared with those who had not been catheterised $(18 \%)$. The incidence of bacteriuria was directly related to the duration of catheter drainage. Postoperatively, $40 \%$ of patients with sterile urine at the time of prostatectomy developed bacteriuria. There was an increased prevalence of Enterococcus and coagulase-negative Staphylococcus isolates from postprostatectomy bacteriuria compared with preprostatectomy bacteriuria. Based on this information, suggestions can be made regarding the choice of a suitable chemoprophylactic agent and the optimum timing and duration of its administration.

Benign prostatic hypertrophy probably occurs in nearly all men as they grow older ${ }^{1}$ and results in changes in the urinary tract ${ }^{12}$ which, along with the operation of prostatectomy itself, predispose to the development of urinary tract infection. Although, in these patients, bacteriuria is important, ${ }^{3-7}$ reports of its incidence, before and after prostatectomy, vary considerably. ${ }^{8}$ Furthermore, there has been little detailed investigation of the bacteria isolated. For these reasons, a study was set up to establish: (i) the incidence of preprostatectomy bacteriuria and its relation to the frequency and duration of preoperative catheter drainage; (ii) the incidence of postoperative bacteriuria and its relation to the duration of postprostatectomy catheter drainage; and (iii) the identity and antibiotic sensitivity of the isolated bacteria.

\section{Patients and methods}

Over a two-and-a-half-year period, all patients admitted to the Western Infirmary, Glasgow, for resection of the prostate, and who were not receiving

\footnotetext{
*Present address: Department of Microbiology, St. James' Hospital, Sarsfield Road, Balham, London, SW $128 \mathrm{HW}$.

Accepted for publication 5 May 1982
}

antibacterial therapy at the time of hospital admission, were studied. Patients with acute urinary retention were initially managed by catheterisation and closed bladder drainage; they were operated on as soon as possible, going to theatre with an indwelling catheter already in situ. Prostates estimated to weigh more than 60 to $70 \mathrm{~g}$ were removed by an open enucleative procedure; those estimated to weigh less, were resected transurethrally. After the operation, urethral catheters drained into a closed collecting system. Irrigation, with sterile water, was undertaken only when required; if necessary, an obstructed catheter was replaced. The urethral catheters were removed as soon as signs of fresh bleeding had ceased. Intravenous fluids and frusemide (two $20 \mathrm{mg}$ injections) were administered in the first 24 hours.

Urine specimens were collected from each patient at approximately $0700 \mathrm{hrs}$ every day from the day of admission until the ninth postoperative day or the day of discharge, whichever was the sooner. Urine samples were collected either by the clean-catch method or by aspiration from the catheter tubing. The samples were refrigerated within minutes of collection. Within three hours of collection, each well-mixed, unspun urine was streaked, by the same person, onto a whole plate of MacConkey agar (Oxoid CM 7B) using a calibrated loop. After 
overnight incubation at $37^{\circ} \mathrm{C}$, colony counts were made. Significant bacteriuria was defined as $\geqslant 100000$ colony forming units per millilitre $(\mathrm{CFU} / \mathrm{ml})$ in any one sample of urine. Lower counts were accepted in catheter specimens if the organism(s) persisted and were isolated from successive specimens. Pyuria was not investigated because of the inevitable haematuria which follows prostatectomy. None of the patients received any local or systemic antibacterial agents before infection was diagnosed.

The isolates were identified using standard methods. ${ }^{910}$ Gram-negative bacilli were identified using the API-20 Enterobacteriaceae system (Monalieu, Vercieu, France). Coagulase-negative Staphyloccoci were identified as described." Antibacterial sensitivities were determined using the method of Stokes. ${ }^{12}$

Statistical analysis was carried out using conventional methods. Each group was compared with the remainder in $2 \times 2$ contingency tables. $\chi^{2}$ and $\mathrm{p}$ values were obtained. Regression equations were calculated using the standard technique of leastsquares for estimating regression parameters. When a weighted regression was considered more appropriate, the standard technique of weighted least-squares was used. ${ }^{13}$

\section{Results}

INCIDENCE OF BACTERIURIA

Two hundred and forty-eight patients underwent prostatectomy; the median age of the patients was 70 yr. Preoperative catheter drainage was required in 67 $(35 \%)$ of 191 patients who underwent transurethral resection, and in $24(42 \%)$ of 57 patients who underwent open prostatectomy. Ninety-one patients were catheterised between one and nine days before prostatectomy; the median duration of preoperative catheter drainage was five days. Twenty-one patients had been catheterised for ten or more preoperative days.

Among the total group of 248 patients, $69(28 \%)$ were found to have preoperative bacteriuria (Table 1). There was no significant difference in the incidence of bacteriuria in patients subsequently having transurethral resection $(29 \%)$ or open prostatectomy $\left(23 \% ; x^{2}=0.931, p=0.4\right)$. There was, however, a highly significant difference between the incidence among patients who had preoperative catheter drainage (44\%) and among patients who had not been catheterised preoperatively $\left(18 \% ; \chi^{2}=\right.$ $18.63, \mathrm{p}<0.001)$.

There was a positive correlation between the incidence of preoperative bacteriuria and the duration of preoperative catheter drainage $(r=$ $0.514, p=<0.001)$. The regression equation (weighted) was: incidence of bacteriuria (percentage) $=18.0+3.1 \times$ number of days of preoperative catheter drainage; $p$ (slope) $<0 \cdot 01$. This implied an average increase of $3.1 \%$ in the incidence of bacteriuria per day of catheter drainage.

After prostatectomy, all the patients were catheterised. The median duration of postoperative catheter drainage was three days in all patients who underwent transurethral resection and in patients who underwent open prostatectomy without preliminary catheter drainage. However, in patients who underwent open prostatectomy after preoperative catheterisation, the median duration of postoperative catheter drainage was four days. Following preoperative catheter drainage, two patients $(3 \%)$ who underwent transurethral resection required postoperative catheterisation for longer than nine days, as did five patients $(21 \%)$ who underwent open prostatectomy. None of the patients who underwent prostatectomy without preliminary catheter drainage required postoperative catheterisation for longer than six days.

Eighty-three patients had sterile urine pre-

Table 1 Incidence of preoperative bacteriuria according to the presence of preoperative bladder catheter drainage and the type of prostatectomy performed

\begin{tabular}{|c|c|c|c|c|c|c|c|}
\hline Operation & $\begin{array}{l}\text { No of } \\
\text { patients }\end{array}$ & \multicolumn{2}{|c|}{$\begin{array}{l}\text { Preoperative } \\
\text { bacteriuria } \\
\text { No } \%\end{array}$} & \multicolumn{2}{|c|}{$\begin{array}{l}\text { Preoperative } \\
\text { sterile urine }\end{array}$} & $x^{2}$ value & $p$ value \\
\hline \multicolumn{8}{|l|}{ Transurethral resection } \\
\hline With preoperative catheter drainage & 67 & 31 & 46 & 36 & $54\}$ & \multirow{4}{*}{$14 \cdot 31$} & \multirow{3}{*}{$<0.001$} \\
\hline Without preoperative catheter drainage & 124 & 25 & 20 & 99 & $80\}$ & & \\
\hline Total & 191 & 56 & 29 & 135 & 71 & & \\
\hline \multicolumn{7}{|l|}{ Open prostatectomy } & \\
\hline With preoperative catheter drainage & 24 & 9 & 38 & 15 & $62\}$ & \multirow{3}{*}{$5 \cdot 08$} & \multirow{3}{*}{$<0 \cdot 025$} \\
\hline Without preoperative catheter drainage & 33 & 4 & 12 & 29 & $88\}$ & & \\
\hline \multirow{2}{*}{\multicolumn{8}{|c|}{ Transurethral resection and open prostatectomy }} \\
\hline & & & & & & & \\
\hline Without preoperative catheter drainage & 157 & 29 & 18 & 128 & $82\}$ & \multirow[t]{2}{*}{$18 \cdot 63$} & \multirow[t]{2}{*}{$<0 \cdot 001$} \\
\hline Total & 248 & 69. & 28 & 179 & 72 & & \\
\hline
\end{tabular}


Table 2 Incidence of postoperative de novo infection according to the type of prostatectomy performed

\begin{tabular}{|c|c|c|c|c|c|c|c|}
\hline Operation & No of patients & $\begin{array}{l}\text { Pos } \\
\text { den } \\
\text { No }\end{array}$ & $\begin{array}{l}\text { ection } \\
\%\end{array}$ & $\begin{array}{l}\text { Pos } \\
\text { steri } \\
\text { No }\end{array}$ & & $x^{2}$ value & $p$ value \\
\hline $\begin{array}{l}\text { Transurethral resection } \\
\text { Open prostatectomy } \\
\text { Transurethral resection and }\end{array}$ & $\begin{array}{l}72 \\
24\end{array}$ & $\begin{array}{r}29 \\
9\end{array}$ & $\begin{array}{l}40 \\
38\end{array}$ & $\begin{array}{l}43 \\
15\end{array}$ & $\left.\begin{array}{l}60 \\
62\end{array}\right\}$ & 0.06 & $0 \cdot 8$ \\
\hline
\end{tabular}

operatively and received prophylactic antibiotics at the time of operation. ${ }^{14}$ Ninety-six patients had sterile urine before and at the time of prostatectomy and did not receive antibiotics before, during or after the operation; 38 (40\%) developed bacteriuria postoperatively (de novo infection ${ }^{8}$ ). There was no significant difference in the incidence of de novo infection in patients who underwent transurethral or open prostatectomy (Table 2 ).

There was a positive correlation between the incidence of postoperative de novo infection and the duration of postoperative catheter drainage $(r=$ $0.474, p<0.01$ ). The regression equation (weighted) was: incidence of bacteriuria (percentage) $=4.392$ $+2 \cdot 21 \times$ number of days of postoperative catheter drainage; $p$ (slope) $<0.05$. This implied an average increase of $2.2 \%$ in the incidence of de novo infection per day of catheter drainage. Although statistical significance was achieved and the rise within the first four days was certain, interpretation of the incidence after the fifth day should be guarded because the number of patients who were catheterised for longer than that was small. Both of the patients catheterised after the operation for ten or more days developed bacteriuria.

\section{BACTERIA ISOLATED FROM BACTERIURIA}

One hundred and nineteen organisms were isolated; 75 from preprostatectomy bacteriuria and 44 from postprostatectomy de novo infection. These results are shown diagrammatically in the Figure. The major differences found between the genera isolated were the increased prevalence of coagulase-negative Staphylococcus and Enterococcus isolates (and a corresponding decrease in Escherichia strains) in the organisms isolated from postprostatectomy de novo infection compared with the organisms isolated from preprostatectomy bacteriuria.

The percentage of all the urinary isolates fully sensitive to various antimicrobial agents are shown in Table 3. In general, the proportion of sensitive isolates appeared to be the same in the pre- and postoperative groups, with the exception of the strains of coagulase-negative Staphylococci among which there was a higher incidence of multiple
Organisms isolated from pre-operative infections

Organisms isolated from post-operative infections

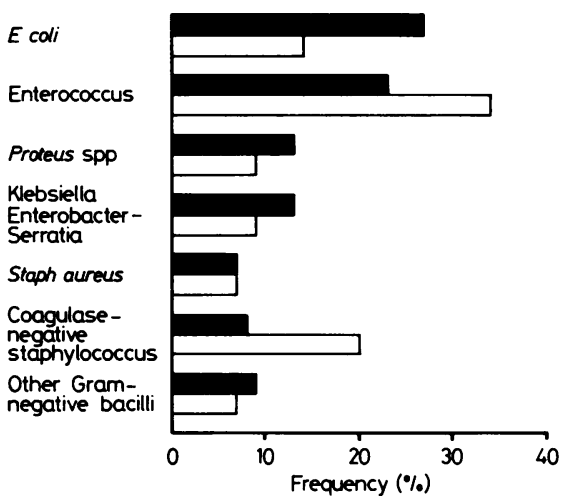

Fig. 1 A diagrammatic representation of the genera of the organisms isolated from preprostatectomy bacteriuria and postprostatectomy de novo infection.

Table 3 Percentages of all urinary isolates fully sensitive to various antimicrobial agents, related to the source of the organisms

\begin{tabular}{lll}
\hline Antimicrobial agent & \multicolumn{2}{l}{ Source of organisms } \\
\cline { 2 - 3 } & $\begin{array}{ll}\text { Preoperative } \\
\text { bacteriuria }\end{array}$ & $\begin{array}{l}\text { Postoperative } \\
\text { de novo infection }\end{array}$ \\
\hline Amikacin & 70 & 61 \\
Ampicillin & 64 & 59 \\
Carbenicillin & 73 & 64 \\
Cephaloridine & 79 & 91 \\
Cephradine & 75 & 77 \\
Gentamicin & 77 & 67 \\
Kanamycin & 75 & 48 \\
Nalidixic acid & 56 & 34 \\
Nitrofurantoin & 86 & 95 \\
Suphafurazole & 51 & 36 \\
Tetracycline & 65 & 52 \\
Tobramycin & 77 & 53 \\
Trimethoprim & 80 & 61 \\
\hline
\end{tabular}

antibiotic resistance in those isolated from postprostatectomy de novo infection. ${ }^{\text {" }}$ 


\section{Discussion}

The incidence of bacteriuria occurring before and after prostatectomy was high in the present study, and was related to the duration of catheter drainage. There was no decrease in the rate of acquired bacteriuria from day to day. This concurs with the findings of other workers ${ }^{15 * 16}$ and supports the suggestion that with closed catheter drainage, the major pathway for entry into the bladder is by migration of bacteria extraluminally in the periurethral space. ${ }^{17}$ It is important to understand the mechanisms of acquisition of bacteriuria because once this has been established, logical methods can be tried to prevent it occurring.

Although techniques of prostatectomy have been described that do not require the use of postoperative indwelling bladder catheters, ${ }^{18-21}$ these are not in common use. In the present study, all the patients were catheterised postoperatively for, on average, three days. This duration is similar to that ( $2 \cdot 9$ days) observed by Collste and Törnqvist. ${ }^{8}$ Some of the patients who had been catheterised preoperatively, required a longer period of postoperative catheter drainage than those who had not. This may have been due to a delay in return of bladder tone, or the persistence of bleeding as these are probably the two main factors necessitating longer postoperative catheterisation. ${ }^{22}$

In the present study the incidence of de novo infection was $40 \%$ after transurethral resection, and $38 \%$ after open prostatectomy. Previous reports of the incidence of de novo infection vary from 6.4 to $69 \cdot 7 \% .^{82-25}$ Some of these differences have been attributed to variations in the diagnostic criterion of significant bacteriuria. ${ }^{826}$ In the present study, the collection of daily urine specimens meant that it was impossible to overlook urinary infection. The high level of de novo infection found is ample justification for routine prophylactic administration of antimicrobial agents, if this can be shown significantly to reduce bacteriuria or its associated complications.

Recent reviews of the prophylactic use of systemic agents in urology ${ }^{27} 28$ concluded that the controversy about the value of antimicrobial prophylaxis in urology had arisen as a result of inadequate and inconsistent methodology. The inappropriate timing and duration of antibiotic administration was criticised. From the evidence presented here, suggestions can be made about the optimum timing and duration of antibiotic administration to prevent postprostatectomy bacteriuria. In general, if a surgical procedure does not exceed two hours in duration, a single preoperative injection of antibiotic should be adequate. ${ }^{29}$ The operation of prostatectomy normally lasts less than two hours, however, because of the period of postoperative catheterisation, single dose prophylaxis is unlikely to be effective. A short course, starting at the time of operation, might be of value.

A rational choice of a suitable chemoprophylactic agent can only be made when the distribution of the genera of the organisms likely to be present, and their probable sensitivities, are known. The most frequent urinary isolate from postprostatectomy de novo infection in patients who received no antibiotics was Enterococcus. In a study comprised primarily of elderly male patients, Gross et $a^{30}$ found that Enterococci were the most frequent cause of urinary tract infections.

In general, in the present study, the pre- and postoperative urinary isolates (with the exception of the postprostatectomy isolates of coagulase-negative Staphylococcus) were sensitive to the antimicrobial agents tested. The properties of an ideal urinary antibacterial agent have been listed. ${ }^{31}$ In the present study, one of the aminoglycosides would appear to be a "good" choice as a chemoprophylactic agent. However, the aminoglycosides have only moderate activity against Streptococci, ${ }^{32}$ and it could be argued that their life-saving value as a therapeutic agent in urology might be lost if they were used routinely for chemoprophylaxis.

Many of the isolates from pre- and postprostatectomy bacteriuria were ampicillin resistant. For several years prior to this study, ampicillin had been used frequently in this Urology Unit for urinary tract infections. Carbenicillin is usually reserved for Pseudomonas infection. ${ }^{33}$ Tetracycline can exacerbate renal disease.$^{34}$ Nalidixic acid has no activity against the most common postprostatectomy urinary isolates, Enterococcus and coagulase-negative Staphylococcus. Although nitrofurantoin is active against these organisms and reaches high levels in the urine, it does not give therapeutic concentrations in the blood and is not indicated when there is a possibility of severe renal infection and septicaemia. ${ }^{33}$ Inadequate tissue concentrations at the time of prostatectomy could mean that other infective complications, such as bacteraemia, or wound infection after open prostatectomy, would not be prevented. Many of the postoperative isolates were resistant to sulphonamide and trimethoprim. All the patients in the present study received frusemide after prostatectomy, as this has been shown to reduce the incidence of urinary tract infection. ${ }^{35} 36$ The administration of cephaloridine with frusemide can result in renal failure. ${ }^{37-39}$ However, cephradine can be used safely in patients with renal failure. ${ }^{40}$

In conclusion, more information is required about the pathogenesis and epidemiology of urinary tract 
infections in patients undergoing prostatectomy before it will be possible to prevent the initiation of bacteriuria. This ideal may never be achieved because several of the predisposing factors may not be preventable. Although a number of non-specific procedures, such as hydration, may be helpful, it is apparent that, for some time at least, the administration of antimicrobial agents will be the main means of reducing the incidence, and effects, of bacteriuria. From the present study, suggestions can be made about a suitable choice of a chemoprophylactic agent and the optimum timing and duration of its administration. The efficacy of its use requires evaluation by trials designed along the lines suggested by Berger and Nager ${ }^{27}$ and Chodak and Plaut. ${ }^{28}$

We thank Mr AG Graham, Mr RF Deane and Mr KF Kyle, Consultant Urologists, Western Infirmary, Glasgow, for access to their patients.

\section{References}

' Blandy JP. Benign prostatic enlargement. Br Med J 1971;i:31-5.

- Turner Warwick R. Whiteside CG, Arnold EP. Bates CP. Worth PHL, Milroy EGJ, Webster JR, Weir J. A urodynamic view of prostatic obstruction and the results of prostatectomy. $\mathrm{Br} \mathrm{J}$ Urol 1973;45:631-45

' Creevy CD, Feeney MJ. Routine use of antibiotics in transurethral prostatic resection: clinical investigation. J Urol 1954;71:61523.

4 Marshall A. Retropubic prostatectomy: a review with special reference to urinary infection. Br J Urol 1967;39:307-28.

s Singh M. Tresider GC. Blandy JP. The evaluation of transurethral resection for benign enlargement of the prostate. $\mathrm{Br} J \mathrm{Urol}$ 1973;45:93-102.

"Wear JB Jr, Haley P. Transurethral prostatectomy without antibiotics. J Urol 1973;110:436-40.

' Sach R, Marshall VR. Prostatectomy: its safety in an Australian Teaching Hospital. Br J Surg 1977;64:210-4

${ }^{*}$ Collste LG, Törnqvist H. Urinary infection and transurethral prostatectomy. Scand J Urol Nephrol 1978;12:7-9.

" Cowan ST. Steel KJ. Manual for the identification of medical bacteria. Cambridge: Cambridge University Press. 1965.

"Cowan ST. Cowan and Steel's Manual for the identification of medical bacteria. 2nd ed. Cambridge: Cambridge University Press, 1974.

" Williams M, Dawson JE, Gemmell CG. Urinary infection with coagulase-negative staphylococci in patients undergoing prostatectomy. J Clin Pathol 1980;33:702-3.

'2 Stokes EJ. Clinical bacteriology. 4th ed. London: Edward Arnold, 1975

${ }^{13}$ Draper NR, Smith H. Applied regression analysis. New York: Wiley, 1966:77-81.

it Williams M, Hole DJ, Murdoch RWG, Ogden AC, Hargreave TB. 48-hour cephradine and postprostatectomy bacteriuria. $\mathrm{Br}$ J Urol 1980;52:311-5.

${ }^{15}$ Garibaldi RA, Burke JP, Dickman ML, Smith CB. Factors predisposing to bacteriuria during indwelling urethral catheterisation. N Engl J Med 1974;291:215-9.

in Warren JW, Platt R, Thomas RJ, Rosner B, Kasse H. Antibiotic irrigation and catheter-associated urinary tract infections. $N$ Engl J Med 1978;299:570-3.

" Garibaldi RA, Burke JP, Britt MR, Miller WA, Smith CB. Meatal colonization and catheter-associated bacteriuria. $N$ Engl J Med 1980;303:316-8.

1* Debenham LS. Ward AE. Retropubic prostatectomy using a nocatheter technique. Br J Urol 1960;32:178-82.

${ }^{14}$ Spencer J. Experience with a no-catheter technique for prostatectomy. BrJ Surg 1967;54:340-3.

${ }^{20}$ Cass AS. Transurethral prostatic resection without catheter drainage. J Urol 1969;101:750-1.

21 Hubmer G, Lipsky H, Petritsch P, Eppich F. Prostatectomy with a no-catheter technique. Br J Urol 1977;49:315-7.

22 Symes JM, Hardy DG, Sutheris K, Blandy JP. Factors reducing the rate of infection after transurethral surgery. $\mathrm{Br} J$ Urol 1972;44:582-6.

${ }^{23}$ Genster HG, Madsen PO. Urinary tract infections following transurethral prostatectomy: with special reference to the use of antimicrobials. J Urol 1970;104:163-8.

${ }^{24}$ Brehmer B, Madsen PO. Route and prophylaxis of ascending bladder infection in male patients with indwelling catheters. $J$ Urol 1972;108:719-21.

is Shapiro SR, Santamarina A, Harrison JH. Catheter-associated urinary tract infection: incidence and a new approach to prevention. J Urol 1974;112:659-63.

26 Jackaman FR, Chisholm GD. Urinary infection and prostatectomy. Br J Urol 1975;47:545-8.

27 Berger SA, Nager H. Antimicrobial prophylaxis in urology. J Urol 1978;120:319-22.

${ }^{2 *}$ Chodak GE, Plaut ME. Systemic antibiotics for prophylaxis in urologic surgery: a critical review. J Urol 1979;121:695-9.

${ }^{29}$ Keighley MRB, Burdon DW. Antimicrobial prophylaxis in surgery. London: Pitman Medical, 1979:23-32.

${ }^{30}$ Gross PA, Harkary LM, Barden GE, Flower MF. The epidemiology of nosocomial urinary tract infection. Am J Med Sci 1976;272:75-81.

"Marsh FP. Natural and therapeutic defence against urinary infection. In: Blandy JP, ed. Urology. Oxford: Blackwell Scientific Publications, 1976: 183-94.

${ }^{32}$ Garrod LP, Lambert HP, O'Grady F. Antibiotic and chemotherapy. 5th ed. Edinburgh: Churchill Livingstone, 1981:115-54.

${ }^{33}$ Williams JD, Kosmidis J, Geddes AM. Chemotherapy of urinary tract infections. In: Geddes AM, Williams JD, eds. Current antibiotic therapy. London: Churchill, 1973:99-112.

${ }^{34}$ Stott RB, Cameron JS, Ogg CS, Toseland P. Tetracycline and impaired renal function. Lancet 1971 ;ii: 1378-79.

${ }^{35}$ Essenhigh DM, Eustace BR. The use of frusemide (Lasix) in the post-operative management of prostatectomy. $\mathrm{Br} \mathrm{J}$ Urol 1969;41:579-95.

${ }^{36}$ Essenhigh DM, Clayton CB, Taha MA. The use of Lasix (Frusemide) in the prevention of urinary infection following prostatectomy. Br J Urol 1970;42:450-6.

${ }^{37}$ Foord RD. Cephaloridine and the kidney: In: Hamoa Umezava, ed. Progress in antimicrobial and anticancer chemotherapy. Baltimore: University Park, 1969; I:597-604. (Proceedings of the 6th International Congress of Chemotherapy, Tokyo, 1969).

${ }^{38}$ Dodds MG, Foord RD. Enhancement of potent diuretics of renal tubular necrosis induced by cephaloridine. Br J Pharmacol 1970;40:227-36.

${ }^{39}$ Lawson DH, McAdam RD, Singh H, Gavras H, Linton AL. The nephrotoxicity of cephalorine. Postgrad Med J 1970;suppl 46:36-8.

${ }^{* 0}$ Solomon AE, Briggs JD, McGeachy R, Sleigh JD. The administration of cephradine to patients in renal failure. $\mathrm{Br} J$ Clin Pharmacol 1975;2:443-48.

Requests for reprints to: Dr M Williams, Department of Microbiology, St James' Hospital, Sarsfeld Road, Balham, London, SW12 8HW, England. 